UDC 331; DOI 10.18551/rjoas.2022-01.04

\title{
THE ROLE OF HUMAN RESOURCES MANAGEMENT ON EMPLOYEE SATISFACTION OF PT. PANIN DUBAI SDAYA BANK
}

\author{
Budiono I Nyoman*, Aris \\ Da'wah Management, Faculty of Ushuluddin, Adab and Da'wah - \\ Parepare State Islamic Institute, Indonesia \\ *E-mail: inyomanbudiono@iainpare.ac.id
}

\begin{abstract}
This study aims to determine how the role of human resource management on employee job satisfaction in supporting organizational performance. With an empirical approach and using field studies, this research seeks to find out information about the process of employee recruitment and selection, job orientation, job placement, training and human resource development within the company. The results of the study show that the series of employee recruitment and selection processes went well and employees were satisfied with the process. The orientation and work placement carried out by the management are also well appreciated by the employees. In addition, the development of the quality of human resources is reflected in the number of trainings attended by employees.
\end{abstract}

\section{KEY WORDS}

Human resource management, employee satisfaction, Panin Dubai SDaya Bank.

Bank is a business entity that collects funds from the public in the form of savings and distributes them to the public in the form of credit and or other forms with the aim of improving the standard of living of many people. In the banking system (Febrianti, 2020), there are two operational systems, namely conventional banks and Islamic banks (Hafez \& Halim, 2019). Islamic banks are banks that carry out business activities based on SDaya principles (Lidyah, 2018; Nugroho, et al. 2017), or Islamic legal principles regulated in the Fatwa of the Indonesian Ulema Council such as the principles of justice (Choiriyah, et al. 2021) and balance ('adl wa tawazun), benefit (maslahah), universalism (natural), and do not contain gharar, maysir, usury, injustice and unlawful objects (Indonesia Law No. 21 of 2008).

The development of Islamic banking in Indonesia is currently quite encouraging where in December 2018 (Utama, 2018) there were 14 SDaya Commercial Banks with a total of 1875 offices (Branch Offices, Sub-Branch Offices and Cash Offices) and a workforce of 49516 employees. While Conventional Banks that have SDaya Business Units are as many as 20 banks with 1875 offices and a workforce of 4918 employees. The total assets of Islamic Commercial Banks and SDaya Business Units are 477327 Trillion Rupiah with a total of 2962 ATM Network units. SDaya People's Financing Bank (BPRS) with a total of 495 offices and a workforce of 4918 employees. Financial performance for Islamic Commercial Banks is generally quite good with a CAR value of $20.39 \%$, TPF of 257,606 T, FDR of $78.53 \%$ and NPF and Net NPF of $3.26 \%$ and $1.95 \%$, respectively. In the SDaya Business Unit, the financial performance is also quite good, as indicated by the TPF figure of Rp. 114.222T, FDR $103.22 \%$, NPF and Net NPF $2.15 \%$ and $1.39 \%$, respectively.

Like other Islamic banks, Bank Panin Dubai Syariah also has challenges to improve human resources who have competence in the field of Islamic banking. To find out more about the role of human resource management on employee satisfaction at PT. Bank Panin Dubai Syariah Makassar Branch, so we feel the need to conduct research, especially in terms of employee recruitment, selection, placement, training and human resource development.

\section{LITERATURE REVIEW}

According to Rivai and Sagala (2009), recruitment is essentially a process of determining and attracting applicants who are able to work in a company. This process 
begins when applicants are searched for and ends when their applications are submitted / collected. The result is a collection of prospective new employee applicants to be selected and selected. In addition, recruitment can also be said as a process to get a number of qualified human resources (employees) to occupy a position or job in a company.

The selection process is intended so that the applicants who have been collected can be selected as the best to become employees of the company in accordance with predetermined criteria. The entire series of processes carried out in selecting applicants to be accepted as employees according to predetermined criteria is called Selection. A good selection process will produce good employees and make a positive contribution to the company. A bad selection process will result in bad employees and usually have a negative impact on the company. To carry out a good selection process, of course, it must involve an $\mathrm{HR}$ team that is truly professional, objective and has high integrity and responsibility for the company. The system of tribalism, nepotism, bribery and others that have a negative impact on the company must be completely avoided.

Introduction (Orientation) is one of the operational functions of Human Resource Management which is intended so that new selected employees can get to know more about the company where they work. This introduction includes the introduction of people consisting of employees in one field or another, direct and indirect supervisors, customers and related business partners as well as the company's physical equipment and the field of work undertaken by the employee concerned. An employee introduction or orientation program is very important to do so that new employees can find out what is related to their work and can make adjustments and generate feelings of pleasure and joy at work.

In larger companies, usually the introduction program (orientation) is coupled with a training program which can take one week, one month, 3 months, 6 months or even 1 year depending on the discretion of each company and usually according to the position of the new employee: the higher the position of the new employee, the longer the training program. After that, it is coupled with an internship program called On the Job Training (OJT).

After the Employee Introduction (Orientation) is carried out, both a simple introduction, and an introduction through training and OJT programs, new employees will be placed according to the employee's talents and company needs. In the concept of management, the term "The Right Man on the Right Place" means the right person occupies the right position. Misplacement of work that is not in accordance with the interests of employees is usually fatal when the employee has just come to work. This is of course very detrimental to the company because recruiting employees requires large costs and takes a long time. For this reason, the placement of employees must be based on a thorough evaluation of the employees concerned.

Training is given to new employees as well as existing employees. The training provided to new employees is generally company-oriented and an introduction to the field of work that the employee will undertake. Meanwhile, the training provided to existing employees is usually in the form of socializing new programs that will be applied to companies related to their field of work, training in deepening tasks, leadership training and others. The training provided to existing employees is usually oriented to the development of these employees and is intended to increase insight and knowledge.

Job satisfaction is the level of pleasure that a person feels for his role or work in the organization. Factors that affect employee job satisfaction include psychological factors, communication factors, physical factors and welfare factors. Psychological factors are factors related to employee psychology, including: work calm, suitability of interests and talents, etc. The communication factor is a good communication situation between superiors and subordinates as well as between co-workers, the better communication the more satisfied employees are at work, physical factors are related to the physical condition of the workplace as well as facilities and infrastructure such as vehicles, computer equipment, etc., the better the physical condition more satisfied employees at work. Welfare insurance factors include compensation and remuneration including insurance, promotions and others, the better the welfare of employees, the more satisfied employees are at work. 


\section{METHODS OF RESEARCH}

This research is a type of field research with qualitative and quantitative methods simultaneously with an empirical approach. To obtain the required information, this study used surveys and interviews with research subjects. The questions asked in the research survey relate to the information to be obtained in this study, such as: the process of recruiting and selecting employees, job orientation, job placement, training, performance appraisal and job satisfaction. The survey was conducted using a questionnaire which was distributed to research subjects and then direct interviews were conducted with randomly selected subjects. To complete the survey the majority of subjects took 10 minutes and the interview took 20 minutes.

This study determines that the sample to be used is the employees of Bank Panin Dubai Syariah Makassar - Indonesia and starts from the manager level, HRD, teller and account officer level. A total of 21 employees were assigned as subjects in this study. The selection of research subjects was based on 2 assumptions, namely: First, organizational performance is identical to employee performance and when employee performance becomes good it will be positively correlated with organizational performance. Knowing the needs and capabilities of HRD in carrying out their duties properly can be a revolutionary tool and a measure for organizational progress. Second, phenomena that do not originate from a social context and take place in a collection of research objects with diverse cultural backgrounds can be generalized (Agarwal and Karahana, 2000).

The data that has been obtained previously will be classified and described in writing so that it is easy to understand. In addition, quantitative analysis will be carried out in determining the percentage of data and drawing conclusions. The data analysis that will be carried out consists of 2 stages related to the role of HRD in the organization and employee job satisfaction in the recruitment, selection, on the job training, placement, employee education and training process, assessment and awarding of rewards.

\section{RESULTS AND DISCUSSION}

Sources of employee recruitment carried out by the company come from various sources such as: employees applying alone/walk in employ, advertisements and promotions, company job postings through the selection process, collaboration with educational institutions, and recommendations for partners, companies and labor agents (see Figure 1).
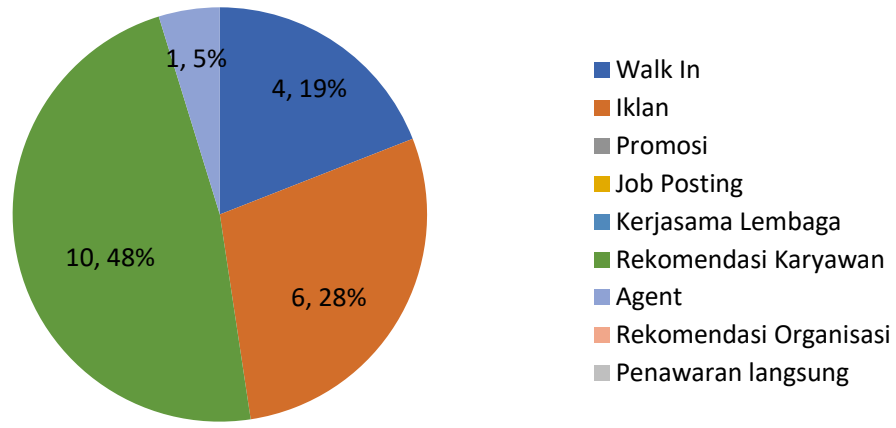

Figure 1 - Employee Recruitment Process Diagram (Source: Rekrutmen Karyawan)

First Diagram shows as many as $48 \%$ of employees who were accepted to work on the recommendation of other employees, followed by $28 \%$ advertisements, $19 \%$ walk-ins and $5 \%$ agents. Meanwhile, recruitment sources that come from promotions, job postings, institutional collaborations, organizational recommendations and direct offers were not found in this study. These results indicate that the recommendations by employees who convey information on prospective new employees already know the prospective employees well and this process is continued with the selection stage by HR managers in accordance with 
company regulations. In addition, advertisements for job vacancies via the internet and employees applying for them are considered quite effective in recruiting employees.

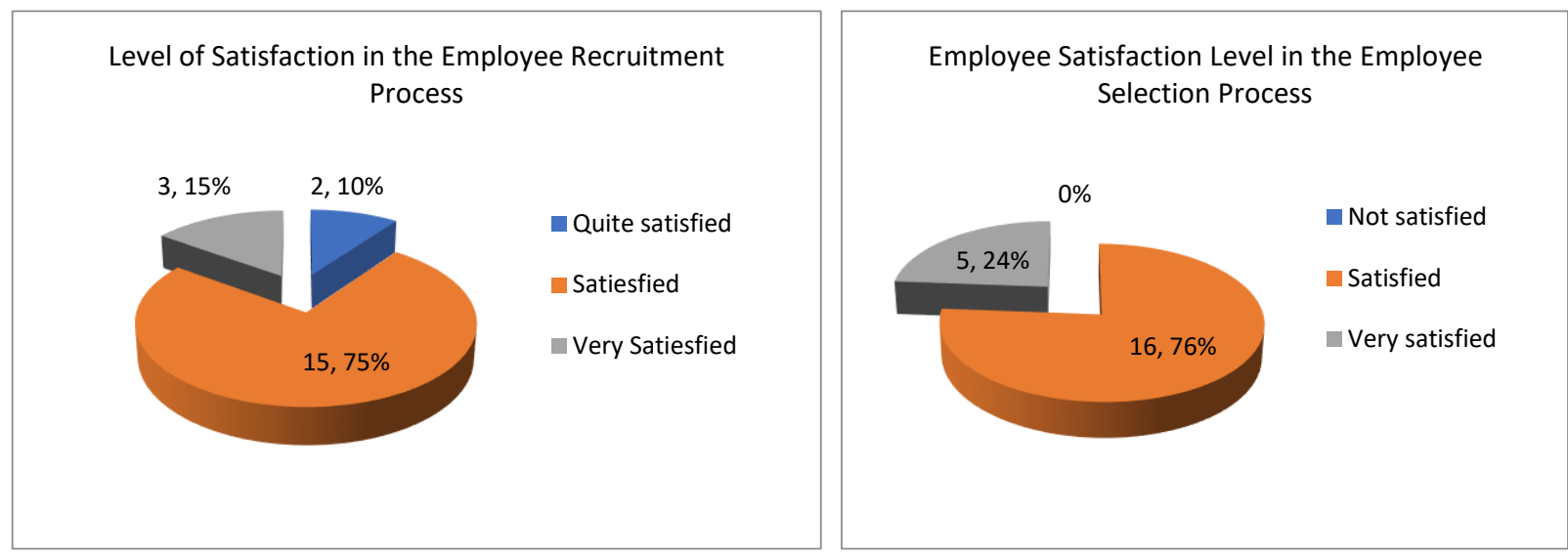

Figure 2 - Diagram of employee satisfaction level of employee recruitment and selection process

Satisfaction in employee recruitment activities carried out by the company's HRD shows that $75 \%$ of employees are satisfied, $15 \%$ are very satisfied and $10 \%$ are quite satisfied. A good picture of the level of employees in this process is related to the recruitment sources used (internet) well-reached by applicants. In addition, the information in job vacancies announcements is very detailed so that applicants can correctly choose the field of work they are interested in.

This process begins with the application file received by the company which will be verified by the HRD (branch leadership and operational manager) regarding the terms and conditions of the documents that have been determined. Furthermore, the results of the verification of employees who successfully pass the file selection will follow the interview, psychotest and medical check stages and finally do a reading and writing test of the Koran. The interview test will be led by the HRD team from the head office, branch managers and operational managers and will be conducted in 2 interview sessions to determine the character, ability and willingness of prospective employees. This test will review the identity, education, work experience and find out the special abilities of prospective employees. In addition, this test aims to clarify the documents submitted during the previous application. Furthermore, psychological tests that are passed by prospective employees need to be carried out to determine the personality characteristics of prospective employees, such as: attitude, personality and intelligence (Feist \& Baron, 2003). The psychological test takes 1 hour to 6 hours using an independent psychological test agency to obtain maximum and accurate results. In carrying out medical tests to ensure the physical readiness of prospective employees by collaborating with health laboratories in medical check-ups. The health test will be carried out when the prospective employee is declared to have passed the interview and psychological test. Al-Quran reading and writing tests and the Koran are carried out on prospective employees of out-sourcing companies and not core employees of the company.

The measure of the level of employee satisfaction in the selection of prospective employees (see Figure 2), was found to be $76 \%$ satisfied and $24 \%$ very satisfied. This shows that the employee candidate selection activities carried out by the company are highly trusted by employees: All stages of prospective employee selection are very informative, fast, professional, organized and effective,

Employee Recognition or Orientation (On the Job Training) is a program carried out by management aimed at preparing employees to do their work as a team (reference). The results showed that $71 \%$ of employees who worked in the company had participated in this program and $29 \%$ did not participate in this program. The implementation of this activity is carried out differently for each position in the company with adjusted material, branch leaders participate in this activity for 1 week, operational managers 2 weeks and new employees 
vary from 3 days to 1 month. Materials for employees were presented regarding the introduction of the company, field of work, scope and work environment and work and principles of being a banker.
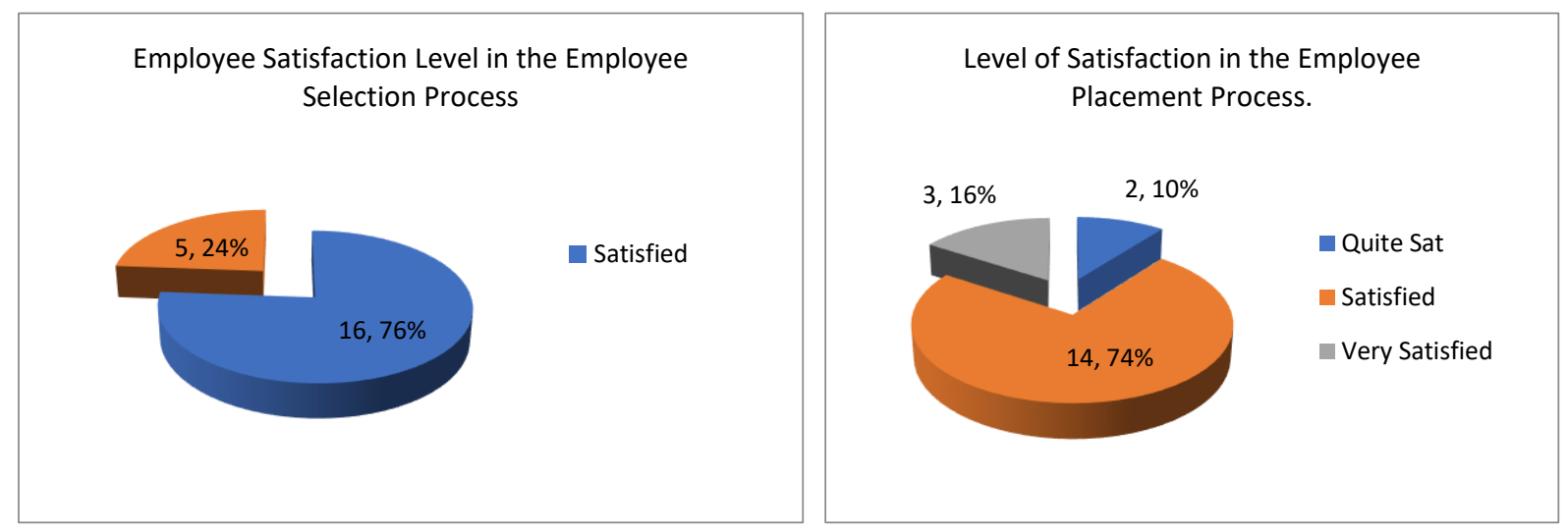

Figure 3 - Diagram of the level of employee satisfaction with the introduction, orientation and job placement by the company

Employee satisfaction in this activity (see Figure 3) was found to be $77 \%$ satisfied, $15 \%$ quite satisfied and $8 \%$ very satisfied. This finding explains that the company's introduction and orientation process can strengthen relationships and work relationships, become a good mentor, support employee performance and facilitate adaptation to the work environment. In addition, orientation can encourage a better understanding of job descriptions; grow the duties and responsibilities of employees to the company.

The placement of employees is regulated based on a decision letter issued by the company's central HRD and for outsourcing employees it is determined by the branch operational manager. The suitability of the placement of employees in certain work fields according to their interests when applying for jobs and this is important in improving employee performance. Meanwhile, the level of employee satisfaction in their work placement (see Figure 3) was found to be $74 \%$ satisfied, $16 \%$ very satisfied and $10 \%$ quite satisfied with the location and work placement. This finding explains that the interests, talents and positions held by employees so far have been in accordance with the wishes of the employees and the abilities of the employees. In addition, the company's needs can be carried out properly due to good employee work placement,

Table 1 - The implementation of education and training for employees

\begin{tabular}{llc}
\hline \multicolumn{1}{c}{ Training Name } & \multicolumn{1}{c}{ Position } & Training Duration \\
\hline Induction Training & Relationship Manager & Day \\
Workshop Consumer & Relationship Manager & 4 Day \\
Training APU-PPT & Relationship Manager, Teller, General Affair, Internal Control. \\
Presentation Skill & Branch Manager & 2-3 Day \\
Introduction to Islamic Banking & Relationship Manager & 1 Day \\
Domestic Operation & Relationship Manager & - \\
Sales and Skill Model & Relationship Manager \& Branch Manager & 1 Day \\
Risk Management & Branch Manager & Day \\
Authenticity of Money & Teller & 1 Day \\
Graphonomy & Teller, General Affair & 1 Day \\
Induction & General Affair, Litigation Officer, Acceptance Staff & $1-7$ Day \\
Education advocate profession & Litigation Officer & 1 Month \\
Islamic Banking Basic Education & Internal Control & 1 Week \\
Service & Security \& General Service & 1 Day \\
\hline
\end{tabular}

The implementation of education and training for employees aims to increase employee knowledge and skills which are carried out as needed (see table 1). New employees receive training for 3 days to 2 weeks and continued with on the job training, while for old employees the training and education focus on products and socialization of the company's new policies. 
Employee satisfaction in employee education and training activities (see Figure 4) carried out by the company shows the percentage of very satisfied $(13 \%)$, satisfied $(67 \%)$, quite satisfied $13 \%$ and dissatisfied $7 \%$. This finding explains that the training carried out by the company went well in adding insight and supporting work, but on the other hand, some employees suggested training in improving the skills and work abilities of employees to be more professional.

Level of Satisfaction in Employee Education and Training Process

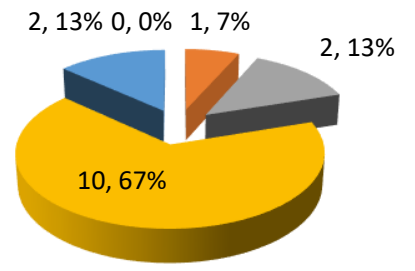

- Very Dissatisfied

not Satisfied

Quite Sat

- Satisfied

- Very Satisfied
Level of Satisfaction with the process of evaluating employee performance

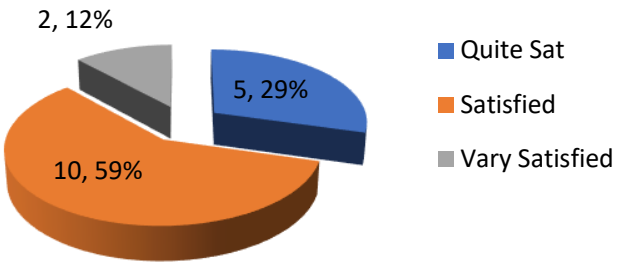

Figure 4 - Diagram of the level of employee satisfaction with education and training, and performance appraisal by the company

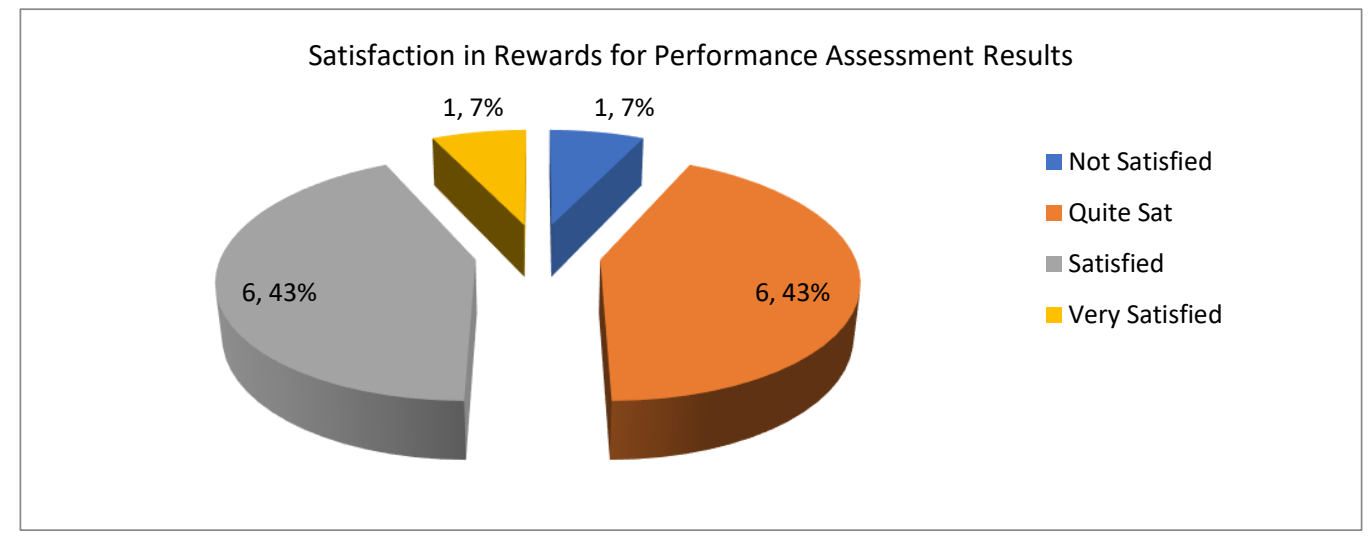

Figure 5 - Diagram of the objectivity of superiors in assessing employee performance

Employee performance appraisal (Performance Appraisal) is an assessment given by superiors to subordinates within a certain period into a predetermined value scale based on the previously agreed Key Performance Appraisal between superiors as appraisers and subordinates as appraisers. The period of this assessment can be done once a year, a year, twice and others according to the discretion of the company where the employee performs his work. In conducting a performance assessment, a leader is required to do it objectively so that employees can know the actual performance to make improvements if their performance is still not as expected, while for employees whose performance has reached the desired standard it needs to be maintained and improved in the future (Selvarajan, 2018; Getnet, et al. 2017). The results of the study in Figure 5 show that $79 \%$ of employees stated that the leader was very objective in assessing the performance of his subordinates and the remaining $21 \%$ stated that they were objective. This shows that the work of the employees has been done well and is assessed positively by the leadership.

Employee satisfaction in the process of giving work values by the company (Figure 4) explains that $59 \%$ said they were satisfied, followed by $29 \%$ of employees who felt quite satisfied and $12 \%$ very satisfied. This finding illustrates that the assessment made by the company on employee performance is very objective and this assessment is expected to be a reference and educate employees to become better at their jobs. 


\section{CONCLUSION}

The magnitude of the development and growth of Islamic banks in Indonesia needs to be addressed with a good management role. It is necessary to increase the competence of human resources owned by Islamic banking. Knowing more about the role of human resource management on employee satisfaction, especially in terms of employee recruitment, selection, placement, training and human resource development needs to be done. With the help of employees from Bank Panin Dubai Syariah Makassar, we conducted a survey and in-person interviews to obtain this information. The results showed that a series of recruitment processes, employee selection, job placement went well and employees showed a high level of satisfaction with the process. The orientation and on the job training carried out by the management strongly support the adaptation of employees to their work environment. In addition, the development of the quality of human resources which is carried out through training which is attended by employees is very supportive of the work of employees.

\section{REFERENCES}

1. Agarwal, Ritu \& Karahanna, Elena. (2000). Time Flies When You're Having Fun: Cognitive Absorption and Beliefs about Information Technology Usage. MIS Quarterly. 24. 665-694. https://doi.org/10.2307/3250951.

2. Choiriyah, C., Saprida, S., \& Sari, E. (2021). Development of SDaya Banking System In Indonesia. Mizan: Journal of Islamic Law, 5(1), 17-28.

3. Febrianti, E. (2020). The Effect of Lending and Placement of Funds in Other Banks on the Bank's Ability to Increase Profitability. Ilomata International Journal of Management, 1(4), 166-176.

4. Feist, G. J., \& Barron, F. X. (2003). Predicting creativity from early to late adulthood: Intellect, potential, and personality. Journal of research in personality, 37(2), 62-88.

5. Getnet, B., Jebena, T., \& Tsegaye, A. (2014). The effect of employees' fairness perception on their satisfaction towards the performance appraisal practices. International Journal of Management and Commerce Innovations, 2(1), 174-210.

6. Hafez, H.M. \& Halim, M. (2019). The efficiency of Islamic banks versus conventional banks: an empirical study of an emerging economy. Banks and Bank Sys., 14(2), 50-62.

7. H. Hadari Nawawi, 2001. Perencanaan SDM Untuk Organisasi Profit Yang Kompetitif. Gajahmada University Pers. Yogyakarta.

8. Herry Sutanto. \& Khaerul Umam, 2013. Manajemen Pemasaran Bank Syariah: Pustaka Setia, Bandung.

9. Fahmi, I. 2015. Manajemen Perbankan Konvensional \& Syariah. Mitra Wacana Media.

10. Ikatan Bankir Indonesia, Memahami Bisnis Bank. Gramedia Pustaka Utama, Jakarta.

11. Khaerul Umam, 2013. Manajemen Perbankan Syariah. Pustaka Setia, Bandung.

12. Kasmir, 2000. Manajemen Perbankan. Raja Grafindo Persada, Jakarta.

13. Lidyah, R. (2018). Islamic Corporate Governance, Islamicityfinancial Performance Index And Fraudat Islamic Bank. Jurnal Akuntansi, 22(3), 437-453.

14. Nugroho, L., Utami, W., Sukmadilaga, C., \& Fitrijanti, T. (2017). The Urgency of Allignment Islamic Bank to Increasing the Outreach (Indonesia Evidence). International Journal of Economics and Financial Issues, 7(4).

15. Rivai., R.V. \& Sagala., E. J. (2009: 147-185). Manajemen Sumber Daya Manusia Untuk Perusahaan. Dari Teori ke Praktek. Peneribt Rajawali Pers. Jakarta.

16. Selvarajan, T. T., Singh, B., \& Solansky, S. (2018). Performance appraisal fairness, leader member exchange and motivation to improve performance: A study of US and Mexican employees. Journal of Business Research, 85, 142-154.

17. Utama, A. S. (2018). History and development of Islamic banking regulations in the national legal system of Indonesia. Al-'Adalah, 15(1), 37-50.

18. Anonymous. Undang-undang Nomor 21 Tahun 2008 Tentang Perbankan Syariah (bingj.com) 